\title{
Climate and health concerns of Montana's public and environmental health professionals: a cross-sectional study
}

\author{
Lori Byron ${ }^{*^{*}}$ (D) and Karen L. Akerlof ${ }^{2 \dagger}(\mathbb{D}$
}

\begin{abstract}
Background: Rural health professionals stand at the forefront of community response to climate change, but few studies have assessed their perceptions of the threat. Further, no previous study has compared the opinions of environmental to public health professionals or extensively analyzed the factors related to these experts' climate beliefs, risk perceptions, and issue prioritization.

Methods: In conjunction with the Montana Climate Assessment's 2021 Special Report on Climate Change and Human Health, the 479 members of the Montana Public Health Association and Montana Environmental Health Association were surveyed during September-October 2019, with 39\% completing the survey. We summarized descriptive data about their perceptions of local climate-related changes and their beliefs that global warming is happening, is mostly human-caused, is a risk to human health, and that their offices and others should take action. We also evaluated which sociodemographic and risk perception factors related to these climate beliefs, risk perceptions, and workplace issue prioritization.
\end{abstract}

Results: Health professionals in Montana, a politically conservative state, demonstrated high levels of awareness that global warming is happening, human-caused, and a threat to human health, well above reported rates of public concern. Eighty-eight percent said that global warming is occurring and $69 \%$ that it is mostly anthropogenic. Sixty-nine percent said that their own health was already affected by climate, and $86 \%$ said they were already seeing at least one climate change-related event in their communities. Seventy-two percent said that their departments should be preparing to deal with climate change's health effects, but just 30\% said that it is currently happening. We found no statistically significant differences between Montana environmental health and public health professionals in regression models predicting climate beliefs, risk perception, and prioritization. As in studies of the public, political ideology and the observation of local climate-related changes were the strongest factors.

Conclusions: Montana environmental and public health officials said that departmental action was needed on climate change, indicating the readiness of rural health professionals to take action. Further studies of health professionals in rural regions are warranted.

Keywords: Climate change, Risk perception, Rural populations, Public health, Environmental health, Survey, Global warming

\footnotetext{
* Correspondence: Ibyron1@alumni.jh.edu

${ }^{\dagger}$ Lori Byron and Karen L. Akerlof contributed equally to this work.

'Lori Byron, MS, MD, 2020 Alumna, Energy Policy and Climate Program,

Johns Hopkins University, 3400 North Charles Street, Baltimore, MD

21218-2608, USA

Full list of author information is available at the end of the article
}

(C) The Author(s). 2021 Open Access This article is licensed under a Creative Commons Attribution 4.0 International License, which permits use, sharing, adaptation, distribution and reproduction in any medium or format, as long as you give appropriate credit to the original author(s) and the source, provide a link to the Creative Commons licence, and indicate if changes were made. The images or other third party material in this article are included in the article's Creative Commons licence, unless indicated otherwise in a credit line to the material. If material is not included in the article's Creative Commons licence and your intended use is not permitted by statutory regulation or exceeds the permitted use, you will need to obtain permission directly from the copyright holder. To view a copy of this licence, visit http://creativecommons.org/licenses/by/4.0/ The Creative Commons Public Domain Dedication waiver (http://creativecommons.org/publicdomain/zero/1.0/) applies to the data made available in this article, unless otherwise stated in a credit line to the data. 


\section{Background}

Anthropogenic climate change contributes to a wide array of increased human physical and mental health risks that manifest differently across communities due to varying hazards and vulnerabilities [1,2]. While urbanization represents one of four global mega-trends tracked by the United Nations [3], much of the world's population remains rural: $45 \%$ as of 2018 [4]. In the United States, rural areas constitute $97 \%$ of land area and $19 \%$ of the population [5]. These areas have distinct characteristics with implications for climate adaptation and health. Their economies are often closely tied to natural resources and agriculture with limited community capacity to adapt due to poverty and other social vulnerabilities [6, 7]. In the United States, rural communities are also less likely to be concerned about climate than those in urban areas [8]. Most of Montana's population is rural (65\%) [9]. In 2019, estimates placed 50 of the state's 56 counties as less likely on average to say global warming is happening than the national average $(67 \%)[8,10]$.

Environmental and public health professionals recognize that environmental conditions affect human health $[11,12]$ and have called for action on climate change [13]. The Lancet Commission described tackling climate change as the greatest public health opportunity of the twenty-first century [14]. Because health is something that most people care about [15], communicating about the health effects of climate change can potentially help governments connect with wide audiences on the issue [16, 17]. Moreover, environmental and public health professionals, particularly nurses, are viewed as "trusted messengers" by the public; indeed, nurses have been the most trusted profession for the past 17 years in the Gallup Polls [18].

In this study we surveyed Montana environmental and public health professionals regarding their perceptions of climate change, its effect on human health, and the need for their offices and others to take action. Further, we analyzed how these perceptions relate to various factors, including sociodemographic and professional characteristics. To our knowledge, the climate risk perceptions of environmental and public health professionals have never been compared, nor have the climate change risk perceptions of health professionals in a frontier region of the United States like Montana been studied. Due to the importance of these professions for successful rural climate adaptation in their roles as content experts and trusted messengers [19], this study thus contributes a novel dimension to a growing literature on the role of health professionals in addressing climate change.

\section{Montana's changing climate}

Montanans are already experiencing impacts of climate change, such as fewer snow days and longer fire seasons
[20]. We conducted this study of health professionals in association with Montana's 2021 climate and health report: Climate Change and Human Health in Montana: a Special Report of the Montana Climate Assessment, 2021 [19]. Released in December 2020, the report details current and projected health-related impacts of climate change in Montana based on increased temperatures, changes in precipitation patterns, altered ranges for infectious disease vectors, increased wildfires, and increased stress on crops (which can affect food supply, nutritional content, and cost of foods).

Montana also serves as home to a number of vulnerable populations who may be particularly affected by climate change [21]: rural residents, laborers in outdoor occupations, and indigenous communities. Montana is relatively sparsely populated with 6.8 people per square mile [22] compared to 92.9 persons per square mile nationally [23]. Outdoor occupations such as farming, fishing, forestry, construction, and extraction represent 65 out of every 1000 state jobs [24]. Indigenous residentswho like other racial and ethnic groups may be more socially vulnerable with fewer resources to adapt-comprise $6.6 \%$ of Montana's population [22] versus $1.3 \%$ nationally [25].

\section{Climate change beliefs and risk perception}

Climate change is frequently viewed by the lay public as abstract and distant in time and effect [26, 27]. People construe climate change as most likely happening elsewhere, to other people, or in the future. These characteristics of public risk perception can help explain why people choose not to engage in activities that might reduce the threat. Studies of risk perception suggest that perceived threat susceptibility and severity are important determinants of people's behavioral responses [28, 29]. Hence it is notable that only 34\% of Montanans in 2019 were likely to say that climate will harm them personally in the future, based on downscaled national survey estimates [10], compared to $42 \%$ nationally. (In 2020, Montana and U.S. percentages have increased, but the discrepancy remains; since this survey was conducted in 2019, 2019 data from Yale is cited.)

Public opinion data demonstrates consistently lower climate concern in Montana than nationally, typically by between 5 and 10 percentage points. The 2019 Yale Climate Opinion Maps estimate that $60 \%$ of Montana residents say that global warming is happening $(67 \%$ nationally), while $45 \%$ say it is mostly human-caused (53\% nationally), and $54 \%$ of Montanans are worried about it (60\% nationally) [10]. Climate change perceptions have been well-documented as correlating with political affiliation, ideology, and worldviews [30]. Indeed, Montana is ranked as a "highly conservative" state according to 2018 Gallup data [31]. 


\section{Views of environmental and public health professionals on climate change}

Public and environmental health professionals play an important role in climate adaptation [32] but typically have different organizational roles, expertise, and responsibilities for climate-related issues. For example, the Montana Public Health Association represents nurses, nutritionists, researchers, health educators, physicians and other licensed health practitioners (personal communication), while the Montana Environmental Health Association's members include largely sanitarians, food inspectors, and disaster management personnel (personal communication). But few studies have assessed the climate change views of these officials [33]. Our academic literature search identified five U.S. studies of public health and/or environmental health professionals [34-38], three statewide studies [39-41] and three of physicians [42-44]. Other studies of health professionals' views remain in the grey literature, such as surveys of Oregon officials [45] and members of the Association of State and Territorial Health Officers (ASTHO) [46]. Because researchers typically employ somewhat differently phrased survey questions and sampling strategies, comparisons are difficult, but in reviewing the 11 academic studies (Table 1; Additional Files 1, Supplementary Tables 1-2), we found:
- The majority of health professionals say that climate change is impacting their communities now with higher percentages saying they anticipate future impacts (Additional Files 1, Supplementary Tables 1-2);

- Identification of specific climate health impacts occurring in jurisdictions remains low, often at 50\% or less (Table 1) with higher levels of concern for future climate health impacts than the present;

- Studies of National Environmental Health Association members $[38,48,49]$ indicate somewhat lower levels of climate change concern than surveys with public health officials; and

- Few say that addressing climate change is a priority for their department (Additional Files 1, Supplementary Table 1).

Previous climate and health studies have surveyed environmental health as well as public health professionals, but no study to our knowledge has directly compared the two groups. In Syal and colleagues' survey of environmental health directors in 2011 [37], only 46\% said that the health effects of climate change in their jurisdiction would be serious. In surveys conducted with $\mathrm{Na}$ tional Environmental Health Association members, a little more than a third of respondents (39\%) were concerned in 2017 about the effects of increased asthma,

Table 1 Surveys of U.S. public and environmental health professionals

\begin{tabular}{|c|c|c|c|c|c|}
\hline & Authors / citation & $\begin{array}{l}\text { Survey } \\
\text { population }\end{array}$ & $\begin{array}{l}\text { Study } \\
\text { year }\end{array}$ & Current health impacts & Future health impacts \\
\hline \multirow[t]{4}{*}{ Public health } & $\begin{array}{l}\text { Maibach, Chadwick, } \\
\text { McBride, Chuk, Ebi, \& } \\
\text { Balbus [34] }\end{array}$ & $\begin{array}{l}\text { Dept } \\
\text { directors } \\
(\mathrm{NACCHO})\end{array}$ & $\begin{array}{l}2007- \\
2008\end{array}$ & $\begin{array}{l}12 \text { impacts: } 13 \% \text { unsafe sewage/septic- } \\
56 \% \text { heat-related illness }\end{array}$ & $\begin{array}{l}59 \% \text { jurisdiction will experience more } \\
\text { serious health impacts in next } 20 \text { years }\end{array}$ \\
\hline & $\begin{array}{l}\text { Roser-Renouf, Maibach, \& } \\
\text { Li [35]; NACCHO (report) } \\
\text { [47] }\end{array}$ & $\begin{array}{l}\text { Dept } \\
\text { directors } \\
\text { (NACCHO) }\end{array}$ & $\begin{array}{l}2011- \\
2012\end{array}$ & $\begin{array}{l}12 \text { impacts: } 11 \% \text { unsafe sewage/septic- } \\
54 \% \text { heat-related illness }\end{array}$ & $\begin{array}{l}61 \% \text { jurisdiction will experience more } \\
\text { serious health impacts in next } 20 \text { years }\end{array}$ \\
\hline & Bedsworth [39] & $\begin{array}{l}\text { Officers } \\
\text { (California) }\end{array}$ & 2007 & - & $\begin{array}{l}94 \% \text { very/somewhat serious threat; } 9 \\
\text { impacts: } 44 \% \text { food-borne illness- } 91 \% \\
\text { extreme weather }\end{array}$ \\
\hline & $\begin{array}{l}\text { Polivka, Chaudry, \& } \\
\text { Crawford [36] }\end{array}$ & $\begin{array}{l}\text { Dept } \\
\text { nursing } \\
\text { directors }\end{array}$ & 2010 & $\begin{array}{l}11 \text { impacts: < } 40 \% \text { malnutriton-58\% } \\
\text { vector-borne diseases }\end{array}$ & $\begin{array}{l}65 \% \text { jurisdiction's CC health impacts } \\
\text { more serious within } 20 \text { years }\end{array}$ \\
\hline \multirow{2}{*}{$\begin{array}{l}\text { Public and } \\
\text { environmental } \\
\text { health }\end{array}$} & $\begin{array}{l}\text { Carr, Sheffield, \& Kinney } \\
{[40]}\end{array}$ & $\begin{array}{l}\text { Officials } \\
\text { (New York) }\end{array}$ & 2009 & $\begin{array}{l}12 \text { impacts: } 25 \% \text { air quality-50\% storms, } \\
\text { hurricanes, floods }\end{array}$ & $\begin{array}{l}39 \% \text { jurisdiction will experience more } \\
\text { serious health impacts in next } 20 \text { years }\end{array}$ \\
\hline & $\begin{array}{l}\text { Carter, Koman, Cameron, } \\
\text { Ferguson, Jacuzzo, \& } \\
\text { Duvall [41] }\end{array}$ & $\begin{array}{l}\text { Officials } \\
\text { (Michigan) }\end{array}$ & 2019 & $\begin{array}{l}8 \text { impacts: } 12 \% \text { mental health-53\% vector- } \\
\text { borne disease }\end{array}$ & $\begin{array}{l}8 \text { impacts increasing in next } 20 \text { years: } \\
21 \% \text { mental health- } 66 \% \text { vector-borne } \\
\text { disease }\end{array}$ \\
\hline \multirow[t]{2}{*}{$\begin{array}{l}\text { Environmental } \\
\text { health }\end{array}$} & $\begin{array}{l}\text { Syal, Wilson, Crawford, \& } \\
\text { Lutz [37] }\end{array}$ & $\begin{array}{l}\text { Dept } \\
\text { directors }\end{array}$ & 2010 & $\begin{array}{l}12 \text { impacts: } 14 \% \text { malnutrition-49\% air } \\
\text { quality }\end{array}$ & $\begin{array}{l}46 \% \text { jurisdiction's CC health impacts } \\
\text { serious }\end{array}$ \\
\hline & $\begin{array}{l}\text { McAdams, Rehr, } \\
\text { Kobayashi, \& DeArman } \\
\text { [38]; EcoAmerica \& Lake } \\
\text { Research Partners [48, } \\
\text { 49] }\end{array}$ & $\begin{array}{l}\text { Member } \\
\text { survey } \\
\text { (NEHA) }\end{array}$ & $\begin{array}{l}2016 \\
2017\end{array}$ & $\begin{array}{l}5 \text { cited personal impacts: } 35 \% \text { (2016), 33\% } \\
\text { (2017) personally affected by breathing } \\
\text { problems, such as asthma-47\% (2016), } \\
46 \% \text { (2017) affected by summer heat } \\
\text { waves }\end{array}$ & $\begin{array}{l}3 \text { cited impacts of concern (2017): 19\% } \\
\text { health impacts from extreme weather; } \\
24 \% \text { vector-borne diseases; } 39 \% \text { health } \\
\text { impacts from air pollution }\end{array}$ \\
\hline
\end{tabular}


allergies, and cardiorespiratory disease from higher rates of air pollution under climate change [48].

National surveys can also obscure large regional differences. A 2012 study of New York State local health department officials [40] - public and environmental health-found lower levels of concern and expertise than a national survey of members of the National Association of County and City Health Officials [35]. Less than a third (32\%) of New York officials reported local effects from climate change already occurring in their jurisdiction and just $39 \%$ said that climate change posed a threat to public health in the next 20 years. Only one quarter of the respondents perceived climate change as an important priority for their local health department. In a 2009 study of local public health officers in California, Bedsworth [39] found much higher rates of concern and activity than in New York. A vast majority (94\%) said that climate was a very or somewhat serious threat to public health; and majorities of the health departments reported programs in climate-related areas such as extreme heat, air pollution, and infectious disease.

Among the climate and health survey studies, only two to our knowledge have analyzed survey findings to establish the relationship between sociodemographic and professional characteristics, or other variables, on health professionals' climate change perspectives. About half the professionals in Polivka's public health nurses' study in 2010 [36] said that their nursing division has a responsibility to address health-related effects of climate change, but most also said that they were not prepared to do so. A majority identified 4 out of 12 health effects as increased due to climate change with only subgroup differences by political ideology. However, there were differences on other measures by education, age, and political ideology. Less educated respondents were more likely to say that climate change is uncontrollable by humans than those with more years of college; younger respondents were more likely to say that nursing could lessen the health effects of climate change than those who were older; and liberals were more likely to say that climate change was anthropogenic and would have negative impacts than conservatives.

A 2011 study [37] assessed the relationship between environmental health directors' environmental attitudes, political views, gender, and risk perception on implementation of climate adaptation programs in the department. The authors found that environmental attitudes and political views contributed to the risk perception of the directors; gender did not. Forty-nine percent said they felt a responsibility for their department to address the health effects of climate change. Moreover, environmental health directors' climate and health risk perceptions accounted for $27 \%$ of the variance in the scope of climate change impacts addressed within programs.
Sociodemographic and other factors related to climate change beliefs have been better studied with the public. In a meta-analysis of the determinants of climate change beliefs using studies of members of the public from across 56 nations, sociodemographic factors-gender, age, income, education and race-were found to have little effect compared to political affiliation, values, trust in scientists, understanding of the climate science consensus, and experience of local weather change [30]. Van der Linden found similar relationships-though lesser effects from personal experiences-in a study of determinants of climate risk perceptions [50].

Therefore, the climate change beliefs, perceptions, and issue prioritization of health professionals in a rural, conservative state are likely to be affected by its political culture. At the same time, these experts have scientific training, actively engage with colleagues in medical and other scientific communities, and have direct experiences of changes in their community's health [34, 35] that could also potentially influence their levels of issue concern. In order to further explore the risk perceptions of public and environmental health professionals, we pose the following research questions:

RQ1: What are the climate change local observations, beliefs, risk perceptions, and issue prioritization of public and environmental health professionals in Montana, a rural and conservative state?

RQ2: (a) What is the relationship between the professional and sociodemographic characteristics of rural health professionals and their climate change belief and risk perceptions? (b) What is the relationship between the professional and sociodemographic characteristics and climate risk perception of rural health professionals on their prioritization of climate change within their department?

\section{Methods}

We surveyed members of the Montana Public Health Association and Montana Environmental Health Association (MPHA/MEHA) between September 26, 2019 and October 30, 2019. MPHA has 379 members while MEHA is a smaller organization with just 100 members. The organizations' members are widely geographically distributed across the state. At least one member of both MPHA and MEHA works in each of Montana's 52 counties.

The 21-question survey was fielded both on paper and online. On average it took respondents just under $5 \mathrm{~min}$ to complete. At a joint MPHA/MEHA meeting in 
September 2019, members were given the option of completing the survey on paper versus waiting for an upcoming online survey link to be released the following week. The presidents of both organizations sent a link to the survey to their entire membership requesting their participation and notifying them that participants would be entered into a raffle for three $\$ 100$ Amazon gift cards.

Regression analyses were completed in SPSS Statistics 27. Of 271 respondents, 47 were students and 39 did not complete two or more demographic questions, such as professional affiliation. Dropping these respondents from the dataset left a final sample of 185. Researchers have demonstrated that extreme weather events can influence climate change concern [51]. Of note, during 2019, there was a severe early snowstorm in September in Montana, but no severe wildfires in Montana [52, 53]. The survey received Johns Hopkins University IRB approval (Study \#HIRB00009679).

\section{Survey measures}

The questionnaire employed measures adapted from previous studies of health professionals and the public on climate change (see Table 1). The complete surveyincluding each measure's wording-can be found in the Additional File 1. The questions address: 1) local climate change observations and assessments of current and future impacts; 2) climate change beliefs; 3) risk perception; and 4) prioritization of climate action by their offices and others. Demographics assessed in the survey included occupation, age, gender, geographic region, community size, political ideology, race, and ethnicity (See Supplementary Table 3, Additional File 1.) Political ideology was measured on a 1-9 scale with 9 being most conservative.

Local climate change observations and assessments of current and future impacts. Because of the politicization of climate change, the first set of measures did not employ either the term "climate change" or "global warming," but instead asked whether respondents had observed changes in frequency of extreme heat days, late summer drought, flooding, forest fires, and extreme precipitation events in their community. The 2017 Montana Climate Assessment identified these as events that are occurring now and will increase over time in Montana [20]. For the purposes of the regression analyses, the number of reported changes that the professionals reported observing was summed. Respondents were also asked about current and future harm to their health and that of their patients from these impacts.

Climate change beliefs. In order to compare the results of the climate change public opinion questions to national- and state-level data from the Yale Project on Climate Change Communication [10], we asked whether global warming is happening (yes, no, don't know) and its predominant cause (mostly human activity, mostly natural causes, it isn't happening).

Risk perception. Respondents answered questions that asked them to judge whether climate change harms, benefits, or has no effect on human health at different temporal and social scales: 1) whether now or in the future; and 2) whether for yourself, your patients, in Montana, in the United States, or in other countries.

Prioritization in addressing climate change. A final set of questions asked the health professionals to relate how much of a prioritization climate change is-and should be-in their work and that of other professionals. Respondents provided their level of agreement, or disagreement, that the public health and environmental health effects of climate change should be a priority at their workplace (strongly agree-strongly disagree). They indicated whether at their workplace there has been any discussion or work around climate change, and suggested who should be addressing the causes and potential effects of climate change in Montana (businesses, elected officials, city/county governments, Montana state government, federal government, tribal governments, health care providers, public health officials, environmental health officials, individual citizens, non-profits).

\section{Results}

After individuals with two or more missing demographic variables were dropped, the study response rate was $37 \%$ (MPHA) and 44\% (MEHA). The professionals were mostly female $(82 \%)$, white $(94 \%)$, liberal $(50 \%)$, with at least some college education (Table 2; Supplementary Table 3, Additional File 1). Respondents were geographically well-distributed across the state (Supplementary Fig. 1, Additional File 1). Half of the professionals serve in communities of 2000-50,000; another 40\% work in communities of 50,000 or greater; $10 \%$ were in communities under 2500 .

\section{Climate change local observations, beliefs, risk perceptions, and prioritizations of public and environmental health professionals in Montana [RQ1]} Local observations. According to the 2017 Montana Climate Assessment [20], climate change is expected to increase extreme heat days, late summer drought, flooding, forest fire severity, and extreme precipitation events. The majority of respondents $(86 \%)$ said that at least one of these phenomena are already occurring in their community. As shown in Fig. 1, about half of respondents (45 to $62 \%$ ) said these events are already occurring, more than half (57 to $74 \%$ ) said their community's health is currently being harmed by each of these events, and an even higher number said their 
Table 2 Descriptive statistics for the sample

\begin{tabular}{|c|c|c|c|c|c|}
\hline & $n$ & Min & Max & $M$ & $S D$ \\
\hline Age $(18-44 ; 45-64 ; 65+)$ & 185 & 1 & 3 & 1.62 & 0.64 \\
\hline Male & 184 & 0 & 1 & 0.17 & 0.38 \\
\hline White/ Caucasian & 185 & 0 & 1 & 0.94 & 0.24 \\
\hline Education & 180 & 1 & 5 & 3.30 & 0.84 \\
\hline Political ideology & 182 & 1 & 9 & 4.29 & 1.86 \\
\hline Environ health professional & 185 & 0 & 1 & 0.24 & 0.43 \\
\hline Community size $(<2500 ; 2500-50,000 ;>50,000)$ & 184 & 1 & 3 & 2.30 & 0.64 \\
\hline Number of local observed climatic changes & 179 & 0 & 5 & 2.63 & 1.65 \\
\hline Harm to patients & 180 & 0 & 1 & 0.63 & 0.48 \\
\hline GW happening & 185 & 0 & 1 & 0.88 & 0.32 \\
\hline GW human-caused & 182 & 0 & 1 & 0.69 & 0.47 \\
\hline Harm to me & 184 & 0 & 1 & 0.69 & 0.46 \\
\hline Priority for department & 183 & 1 & 5 & 3.96 & 1.09 \\
\hline
\end{tabular}

community's health will be harmed more in the future (68 to $80 \%$ ).

Beliefs. The vast majority of respondents (88\%) said that global warming was happening, with $69 \%$ saying that it is mostly human caused.

Risk perceptions. Regarding perceived risk, 69\% said that climate change was harming their personal health already, and $79 \%$ said that it would harm their personal health in the future.

Prioritization. While almost three out of four health professionals said that climate change should be a priority at their workplace $(73 \%$, somewhat agree or strongly agree), less than a third said there had been any discussion or work on the topic (30\%). Almost all respondents (93\%) said action is needed to address climate change; only $7 \%$ said no action is needed. Regarding who should take action on climate, $73 \%$ percent said that all of the entities listed should act on climate and $26 \%$ chose one or more: federal government (16\%); environmental health officials (15\%); Montana state government (14\%); elected officials (11\%); city/county governments (11\%); tribal governments (9\%); public health officials (8\%); and individual citizens (8\%); businesses (5\%); non-profits (4\%); and health care providers (2\%), with the percentages showing the total for each individual entity.

\section{The relationship between professional and} sociodemographic characteristics and climate change beliefs and risk perception [RQ2a]

Logistic regression models predicting survey participant selection of the responses that "global warming is happening" and that it is "mostly caused by humans" were

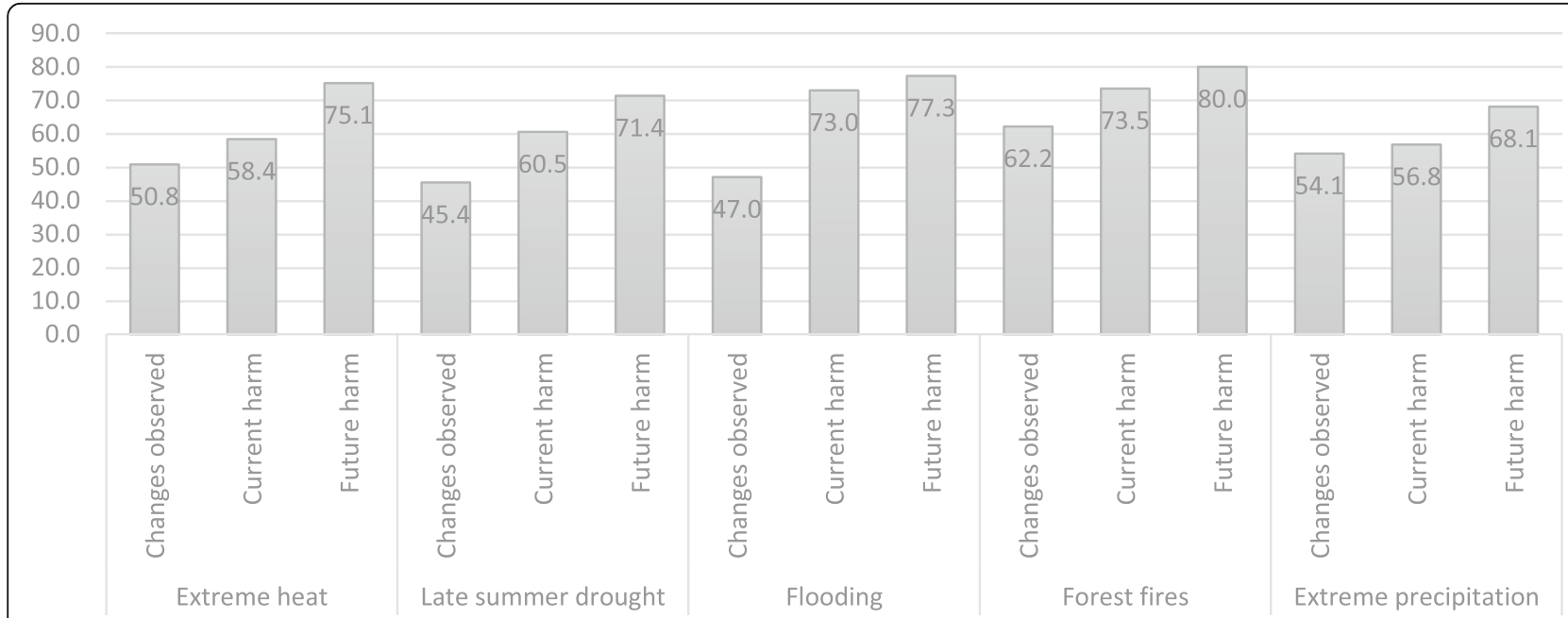

Fig. 1 Montana health professionals' perceptions of climate change-related events in their communities 
both statistically significant (respectively, $\chi^{2}(9)=41.470$, $\left.p<.001 ; \quad \chi^{2}(9)=31.345, \quad p<.001\right) \quad$ (Tables 3-4). The models correctly classified 89.1 and $74.6 \%$ of cases $\left(0.415,0.234\right.$, Nagelkerke $\left.R^{2}\right)$. Of seven predictor variables only two were statistically significant in both the models: political ideology and community size (Tables 34). In both cases, increased conservatism was related to decreased likelihood of saying that global warming is happening and health experts serving communities between 2500 and 50,000 people-e.g., more rural areaswere less likely to say that global warming is happening. Occupation was not a significant predictor in either model.

The model predicting whether respondents say that climate change harms them now was also significant, $X^{2}(10)=55.364, p<.001$. The model correctly classified $77.1 \%$ of cases $\left(0.388\right.$, Nagelkerke $\left.R^{2}\right)$. Of the eight predictor variables only three were statistically significant: education, political ideology, and number of observed local climate changes (Table 5). Higher education was related to an increased likelihood of saying that climate change harms them and the number of observed local climatic changes, while increased conservatism was associated with decreased likelihood of saying they were currently being harmed. Again, occupation was not a statistically significant predictor.

\section{The relationship between professional and} sociodemographic characteristics and risk perception on climate change prioritization [RQ2b]

A linear regression model predicting respondents' level of agreement that environmental and public health organizations should prioritize addressing the effects of climate change (Table 6) was significant $F(11,154)=$ 13.199, $p<.001$, accounting for $48.52 \%$ of the variation in the respondents' agreement across the five-point measure $\left(R^{2}, 0.485\right)$. Of the nine predictors, four were significant. Men were more likely than women and other gender identifications to say that climate change should be a priority. So, too, were those who observed higher rates of local climate changes and those who said that their patients have been harmed from climate change. Conservatives were less likely to say that climate change should be a priority for their organizations.

\section{Discussion}

Public and environmental health professionals in a rural and conservative state demonstrate high levels of understanding that global warming is happening, humancaused, and has immediate health risks. Moreover, they say that their offices should prioritize this issue. However, few say that their offices are addressing the issue (30\%). Like members of the public, factors such as political ideology and experiences of local change in their communities relate the most strongly to the experts' responses.

\section{Comparison to other studies of health care professionals}

In contrast to public concerns about climate change in Montana that typically rank lower than U.S. averages, health care professionals in Montana demonstrated similar or higher climate change concerns and perceived need for action compared to national studies of their colleagues. Most Montana health professionals said that global warming was happening (88\%), mostly human caused $(69 \%)$, and should be a priority at their workplace (73\%). By way of comparison, one of the highest rates of climate concern and prioritization by health professionals was recorded in a 2014 survey of African American physicians in the National Medical Association (NMA) [42], where $61 \%$ were already seeing effects on health; and $75 \%$ said that physicians had a responsibility

Table 3 Logistic regression model predicting the response "global warming is happening"

\begin{tabular}{|c|c|c|c|c|c|c|c|c|}
\hline & \multirow[t]{2}{*}{$B$} & \multirow[t]{2}{*}{$S E$} & \multirow{2}{*}{$\begin{array}{l}\text { Wald } \\
x^{2}\end{array}$} & \multirow[t]{2}{*}{$d f$} & \multirow[t]{2}{*}{$p$} & \multirow{2}{*}{$\begin{array}{l}\text { Odds } \\
\text { ratio }\end{array}$} & \multicolumn{2}{|c|}{ 95\% C.I.for odds ratio } \\
\hline & & & & & & & Lower & Upper \\
\hline Age: $18-44$ years $^{a}$ & -0.74 & 1.52 & 0.24 & 1 & 0.626 & 0.48 & 0.02 & 9.42 \\
\hline Age: $45-64$ years $^{a}$ & -0.98 & 1.46 & 0.45 & 1 & 0.504 & 0.38 & 0.02 & 6.59 \\
\hline Male (Dichotomous) & 1.28 & 1.16 & 1.21 & 1 & 0.270 & 3.58 & 0.37 & 34.68 \\
\hline Race: White/Caucasian (1); other (0) & 0.12 & 1.20 & 0.01 & 1 & 0.919 & 1.13 & 0.11 & 11.91 \\
\hline Education (1-5) & -0.38 & 0.43 & 0.78 & 1 & 0.378 & 0.68 & 0.29 & 1.60 \\
\hline Political ideology (Conservatism ranked high, 1-9) & -0.93 & 0.26 & 12.51 & 1 & 0.000 & 0.40 & 0.24 & 0.66 \\
\hline Occupation: Environmental health (1); public health (0) & -0.72 & 1.00 & 0.52 & 1 & 0.471 & 0.49 & 0.07 & 3.46 \\
\hline Community size: Under 2500 people & -0.11 & 1.29 & 0.01 & 1 & 0.933 & 0.90 & 0.07 & 11.18 \\
\hline Community size: 2500-50,00 people & -1.95 & 0.97 & 4.09 & 1 & 0.043 & 0.14 & 0.02 & 0.94 \\
\hline Number of local observed climatic changes $(0-5)$ & 0.95 & 0.29 & 10.75 & 1 & 0.001 & 2.59 & 1.47 & 4.56 \\
\hline Constant & 8.48 & 3.31 & 6.58 & 1 & 0.010 & 4839.60 & & \\
\hline
\end{tabular}

$n=170$; ${ }^{\mathrm{a} C o n t r a s t}$ category $65+$ years; ${ }^{\mathrm{b} C o n t r a s t}$ category over 50,000 people 
Table 4 Logistic regression model predicting the response "global warming is caused mostly by human activity"

\begin{tabular}{|c|c|c|c|c|c|c|c|c|}
\hline & $B$ & $S E$ & Wald & $d f$ & $p$ & Odds & $95 \%$ C. & Ids ratio \\
\hline & & & & & & & Lower & Upper \\
\hline Age: $18-44$ years* & -0.37 & 0.90 & 0.17 & 1 & 0.680 & 0.69 & 0.12 & 4.01 \\
\hline Age: $45-64$ years* & -0.66 & 0.87 & 0.56 & 1 & 0.454 & 0.52 & 0.09 & 2.88 \\
\hline Male (Dichotomous) & 0.47 & 0.62 & 0.57 & 1 & 0.449 & 1.59 & 0.48 & 5.32 \\
\hline Race: White/Caucasian (1); other (0) & 0.05 & 0.78 & 0.00 & 1 & 0.947 & 1.05 & 0.23 & 4.84 \\
\hline Education (1-5) & -0.09 & 0.27 & 0.10 & 1 & 0.749 & 0.92 & 0.54 & 1.56 \\
\hline Political ideology (Conservatism ranked high, 1-9) & -0.46 & 0.13 & 13.36 & 1 & 0.000 & 0.63 & 0.49 & 0.81 \\
\hline Occupation: Environmental health (1); public health (0) & -0.22 & 0.53 & 0.17 & 1 & 0.679 & 0.80 & 0.29 & 2.26 \\
\hline Community size: Under 2500 people ${ }^{b}$ & -0.76 & 0.75 & 1.03 & 1 & 0.310 & 0.47 & 0.11 & 2.03 \\
\hline Community size: $2500-50,00$ people ${ }^{b}$ & -0.82 & 0.45 & 3.22 & 1 & 0.073 & 0.44 & 0.18 & 1.08 \\
\hline Number of local observed climatic changes (0-5) & 0.35 & 0.13 & 6.71 & 1 & 0.010 & 1.41 & 1.09 & 1.84 \\
\hline Constant & 3.32 & 1.77 & 3.52 & 1 & 0.061 & 27.72 & & \\
\hline
\end{tabular}

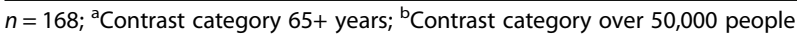

to address climate change with their patients. The relatively high rates of issue awareness and concern found in this study of Montana health professionals-roughly comparable to the 2014 NMA study-may be due in part to population-wide shifts in climate change beliefs during the decade and a half since these studies started [54].

Previous climate and health studies have surveyed environmental and public health professionals, but only two academically published surveys-of officials in Michigan and New York-included both groups within their sample [40, 41]. However, neither of those studies compared the two groups. While studies of National Environmental Health Association members indicated somewhat lower climate risk perceptions than public health professionals [38, 48, 49], our study found no difference in risk perception or climate prioritization between these two groups in Montana.

Differences between health professionals and the public Other research has shown that while health professionals can have very different views on climate change compared to the general public [35], they can also be subject to some of the same politically polarizing influences [34]. The present study illustrates both higher concern levels than the public and the influence of political ideology. In 2019, the Yale Climate Opinion Maps estimated that $60 \%$ of people in Montana were likely to say that global warming is happening $[8,10]$, as opposed this study's finding of $88 \%$ of state public health professionals saying the same that year.

Table 5 Logistic regression model predicting the response "global warming harms ... human health now for the people below [yourself]"

\begin{tabular}{|c|c|c|c|c|c|c|c|c|}
\hline & B & SE & Wald & $d f$ & $p$ & Odds & $95 \% \mathrm{C}$. & Ids ratio \\
\hline & & & & & & & Lower & Upper \\
\hline Age: $18-44$ years $^{a}$ & 0.46 & 0.79 & 0.34 & 1 & 0.562 & 1.58 & 0.33 & 7.50 \\
\hline Age: $45-64$ years $^{a}$ & 0.10 & 0.78 & 0.02 & 1 & 0.896 & 1.11 & 0.24 & 5.13 \\
\hline Male (Dichotomous) & 0.60 & 0.63 & 0.91 & 1 & 0.341 & 1.82 & 0.53 & 6.22 \\
\hline Race: White/Caucasian (1); other (0) & 0.40 & 0.76 & 0.28 & 1 & 0.596 & 1.50 & 0.34 & 6.69 \\
\hline Education (1-5) & 0.72 & 0.29 & 6.18 & 1 & 0.013 & 2.06 & 1.17 & 3.64 \\
\hline Political ideology (Conservatism ranked high, 1-9) & -0.34 & 0.12 & 7.42 & 1 & 0.006 & 0.71 & 0.56 & 0.91 \\
\hline Occupation: Environmental health (1); public health (0) & 0.16 & 0.56 & 0.08 & 1 & 0.774 & 1.17 & 0.39 & 3.50 \\
\hline Community size: Under 2500 people ${ }^{b}$ & 0.71 & 0.77 & 0.86 & 1 & 0.355 & 2.04 & 0.45 & 9.17 \\
\hline Community size: $2500-50,00$ people ${ }^{b}$ & -0.23 & 0.46 & 0.25 & 1 & 0.616 & 0.80 & 0.32 & 1.95 \\
\hline Number of local observed climatic changes (0-5) & 0.60 & 0.15 & 17.10 & 1 & 0.000 & 1.83 & 1.37 & 2.43 \\
\hline Constant & -2.14 & 1.73 & 1.53 & 1 & 0.216 & 0.12 & & \\
\hline
\end{tabular}

$n=170,{ }^{a}$ Contrast category $65+$ years; ${ }^{\text {b } C o n t r a s t ~ c a t e g o r y ~ o v e r ~} 50,000$ people 
Table 6 Regression model predicting agreement with "At my workplace, preparing to deal with the public health and environmental health effects of climate change should be a priority"

\begin{tabular}{|c|c|c|c|c|c|}
\hline & B & SE & B & $t$ & $p$ \\
\hline (Constant) & 4.32 & 0.59 & & 7.33 & 0.000 \\
\hline Age: $18-44$ years $^{a}$ & 0.26 & 0.26 & 0.12 & 1.00 & 0.318 \\
\hline Age: $45-64$ years $^{\mathrm{a}}$ & 0.04 & 0.26 & 0.02 & 0.15 & 0.881 \\
\hline Male (Dichotomous) & 0.40 & 0.19 & 0.13 & 2.04 & 0.043 \\
\hline Race (White/Caucasian) & -0.05 & 0.28 & -0.01 & -0.17 & 0.865 \\
\hline Education (1-5) & -0.08 & 0.09 & -0.06 & -0.88 & 0.380 \\
\hline Political ideology (Conservatism ranked high, 1-9) & -0.21 & 0.04 & -0.35 & -5.10 & 0.000 \\
\hline Occupation: Environmental health (1); public health (0) & -0.13 & 0.18 & -0.05 & -0.72 & 0.475 \\
\hline Community size: Under 2500 people ${ }^{b}$ & -0.19 & 0.25 & -0.05 & -0.78 & 0.435 \\
\hline Community size: $2500-50,00$ people ${ }^{b}$ & -0.27 & 0.14 & -0.12 & -1.90 & 0.060 \\
\hline Number of local observed climatic changes (0-5) & 0.16 & 0.04 & 0.24 & 3.62 & 0.000 \\
\hline Climate change harms my patients (Dichotomous) & 0.59 & 0.15 & 0.26 & 3.80 & 0.000 \\
\hline
\end{tabular}

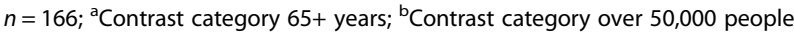

Public health professionals spend their careers addressing threats to the wellbeing of the people within their communities [36], so it might be inferred that they would be more informed about climate change and its health implications than the general public. But public and environmental health professionals, even in Montana, are distinctly different in political ideology and sociodemographic characteristics than state residents in general. As of 2018, 39\% of Montanans said they were conservative, $38 \%$ moderate and $18 \%$ liberal [55]. In contrast, this sample of Montana health professionals was $23 \%$ conservative, $27 \%$ moderate, and 50\% liberal. Additionally, $80 \%$ of the respondents were female [56].

\section{Factors related to professionals' climate change beliefs, risk perceptions, and prioritization}

Political ideology and local experiences of climaterelated changes consistently significantly predicted responses that global warming is happening and mostly human-caused; both of these variables are also strongly correlated with public beliefs about climate change [30]. While local experiences of climate change may be motivated by either physical conditions or previously held beliefs [57], health experts might be expected to be more attuned to changes in conditions, especially as relates to community health. Interestingly, neither education nor expert status (environmental vs. public health) were consistently significant predictors, demonstrating little or no difference between environmental and public health experts, or differences between health professionals with some college experience versus those with advanced degrees. (Education was only a significant predictor of respondents who said that climate change was harming their health now.)

\section{Perceived need for climate action and what professionals can do}

In 2018, at least half of registered U.S. voters--including Democrats, Independents, and liberal/moderate Republicans, but not conservative Republicans--said that citizens, the U.S. Congress, President Trump, their own member of Congress, and/or their local government officials should do more to address climate [58]. Most (73\%) of the respondents in this study of Montana health professionals said that action on climate was needed by all of the above. For those who did not list "all," federal government, environmental health, and state government officials ranked at the top of those the professionals said should be taking action, while health care providers fell at the bottom. The assumption that health care providers do not have a responsibility to address climate change is one that many in health care are attempting to change. Indeed, public and environmental health experts have many opportunities to get involved. Collaborations between local governments, community groups, and public health and environmental health professionals are needed, whether in writing and/or implementing a climate adaptation plan, educating the public on the hazards of extreme hear and the availability of cooling centers, or creating awareness campaigns on the dangers of smoke from forest fires and means of protection. By talking about climate, writing op-eds in the local newspapers, and educating legislators on its health hazards, they can help focus their communities on the decisions they face.

\section{Study limitations}

This study found no significant difference in the beliefs and attitudes of environmental and public health professionals, a topic that had not been previously studied. But 
the number of these health professionals in Montana is relatively small: a larger U.S. study of public and environmental health professionals in other rural areas would be valuable. Although the survey response rate was relatively high with $39 \%$ fully completing the survey, we do not have demographic information for the two member organizations to fully assess the representativeness of the sample. The online survey was advertised by the MEHA and MPHA leadership with no mention climate or global warming, but the $17 \%$ of respondents who participated in a paper version of the study at MPHA's annual meeting met the lead author and may have been aware that the study was about climate change, leading to response bias.

\section{Conclusion}

Montana's health professionals are already aware of climate change's risks and want to see their offices and others more actively engage on the issue. Because of the level of expertise and community knowledge held by these professionals, information about their concerns may be helpful for the public and policymakers, much as climate organizations have spotlighted faith groups as opinion leaders [59]. The positions of trust that these experts hold in their communities potentially make them ideally situated to lead discussions on how to address climate change in rural areas. As health professionals become more aware that a large number of them- even in rural conservative states - are concerned, it may potentially open up spaces for wider conversations with their colleagues and patients.

\section{Abbreviations}

APHA: American public health association; EH: Environmental health; IRB: Institutional review board; MEHA: Montana environmental health association; MPHA: Montana public health association; NEHA: National environmental health association; NMA: National medical association; PH: Public health; US: United States

\section{Supplementary Information}

The online version contains supplementary material available at https://doi. org/10.1186/s12889-021-11737-1

\section{Additional file 1.}

Additional file 2.

\section{Acknowledgements}

We thank the directors and members of the Montana Public Health Association and Montana Environmental Health Association for their time and effort in participating in survey. Also, thank you to the Montana State University Library for the use of Qualtrics. Finally, we thank the other members of the leadership team of the Montana Climate Change and Human Health project and the Montana State Medical Director, Dr. Gregory Holzman.

\section{Authors' contributions}

Both LGB and KLA developed the questionnaire and participated in all aspects of the research. Both authors contributed to the final draft of the paper and approved the submitted version. LGB had full access to all the data in the study and takes responsibility for the integrity of the data and the accuracy of the data analysis. Both authors read and approved the final manuscript.

\section{Authors' information}

LGB practices hospital pediatrics and climate advocacy in rural Montana, after serving 27 years in Indian Health Service. She serves on the EPA's Children's Health Protection Advisory Committee and the American Academy of Pediatrics Executive Committee for the Council on Environmental Health. She is an author on the Montana Climate Change and Human Health project. She earned a MS from Johns Hopkins in Energy Policy and Climate in 2020.

$\mathrm{KLA}$ is an assistant professor in the Department of Environmental Science and Policy at George Mason University and a former adjunct professor at Johns Hopkins University in Energy Policy and Climate.

Funding

This survey project received no financial support, other than from LGB.

\section{Availability of data and materials}

The survey tool, supplementary Tables 1,2, ands 3, and a heat map is located in Additional File 1. The dataset supporting the conclusions of this article is available in an SPSS file in Additional File 2.

\section{Declarations}

Ethics approval and consent to participate

The survey received Johns Hopkins University IRB approval (Study \#: HIRB00009679). Johns Hopkins follows the Common Rule (the Federal Policy for the Protection of Human Subjects), the ethical principles of the Belmont Report, and the Declaration of Helsinki. The first question of the survey tool established informed consent (Additional File 1, Survey Tool). Informed consent was obtained from all subjects.

\section{Consent for publication}

Not applicable.

\section{Competing interests}

The authors, LGB and KLA, declare they have no actual or potential competing financial interests.

\section{Author details}

'Lori Byron, MS, MD, 2020 Alumna, Energy Policy and Climate Program, Johns Hopkins University, 3400 North Charles Street, Baltimore, MD 21218-2608, USA. ${ }^{2}$ Department of Environmental Science and Policy, George Mason University, David King 3032, 4400 University Dr., MS 5F2, Fairfax, VA 22030, USA.

Received: 23 February 2021 Accepted: 29 August 2021

Published online: 30 September 2021

References

1. Crimmins A, Balbus J, Gamble JL, Beard CB, Bell JE, Dodgen D, et al. The impacts of climate change on human health in the United States: A scientific assessment [Internet]. U.S. Global Change Research Program; 2016 [cited 2020 May 19]. Available from: https://health2016.globalchange.gov/ downloads

2. Watts N, Adger WN, Ayeb-Karlsson S, Bai Y, Byass P, Campbell-Lendrum D, et al. The lancet countdown: tracking progress on health and climate change. Lancet. 2017 Mar 18;389(10074):1151-64. https://doi.org/10.1016/ S0140-6736(16)32124-9.

3. United Nations. World population prospects 2019: Highlights [Internet]. Population Division, Department of Economic and Social Affairs, United Nations; 2019. Report No.: ST/ESA/SER.A/423. Available from: https://popula tion.un.org/wpp/Publications/Files/WPP2019_Highlights.pdf

4. United Nations. World urbanization prospects: the 2018 revision [internet]. Department of Economic and Social Affairs, Population Division, United Nations; 2019. Available from: https://population.un.org/wup/Publications/ Files/WUP2018-Report.pdf

5. U.S. Census Bureau. New Census data show differences between urban and rural populations [Internet]. The United States Census Bureau. 2016 [cited 
2020 May 19]. Available from: https://www.census.gov/newsroom/pressreleases/2016/cb16-210.html

6. Dasgupta P, Morton J, Dodman D, Karapinar B, Meza F, Rivera-Ferre MG, et al. Rural areas. In: Field C, Barros V, editors. Climate change 2014: Impacts, adaptation, and vulnerability [Internet]. Cambridge and New York: Cambridge University Press; 2014. p. 613-57. [cited 2020 May 19] Available from: https://gala.gre.ac.uk/id/eprint/14369/

7. Gowda P, Steiner JL, Olson C, Boggess M, Farrigan T, Grusak MA. Agriculture and Rural Communities. In: Reidmiller DR, Avery CW, Easterling DR, Kunkel KE, Lewis KLM, Maycock TK, Stewart BC, editors. Impacts, Risks, and Adaptation in the United States: Fourth National Climate Assessment, Volume II. Washington, DC: U.S. Global Change Research Program; 2018. pp. 391-437. https://doi.org/10.7930/NCA4.2018.CH10.

8. Howe PD, Mildenberger M, Marlon JR, Leiserowitz A. Geographic variation in opinions on climate change at state and local scales in the USA. Nat Clim Chang. 2015 Jun;5(6):596-603. https://doi.org/10.1038/nclimate2583.

9. United States Department of Agriculture. State fact sheets: Montana [Internet]. United States Department of Agriculture, Economic Research Service. 2020 [cited 2020 May 19]. Available from: https://data.ers.usda.gov/ reports.aspx? StateFIPS=30\&StateName=Montana\&ID=17854.

10. Yale Program on Climate Change Communication. Yale climate opinion maps 2019 [Internet]. Yale Program on Climate Change Communication. [cited 2020 May 19]. Available from: https://climatecommunication.yale.edu/ visualizations-data/ycom-us/

11. Definitions of Environmental Health [Internet]. National Environmental Health Association. Par. 2 [cited 2020 May 20]. Available from: https://www. neha.org/about-neha/definitions-environmental-health.

12. Environmental Health [Internet]. American Public Health Association. Par. 1 [cited 2020 May 20]. Available from: https://www.apha.org/topics-andissues/environmental-health.

13. American Lung Association. A declaration on climate change and heath: Climate change is a health emergency [Internet]. 2019. Available from: https://www.apha.org/-/media/files/pdf/topics/climate/190429_declaration_ climate_health.ashx?la=en\&hash=16B91AA9FFE92E5A021524490027D573 FEAE080B

14. Watts N, Amann M, Ayeb-Karlsson S, Belesova K, Bouley T, Boykoff M, et al. The lancet countdown on health and climate change: from 25 years of inaction to a global transformation for public health. Lancet. 2018; 391(10120):581-630. https://doi.org/10.1016/S0140-6736(17)32464-9.

15. Myers T, Nisbet $M$, Maibach $E$, Leiserowitz A. A public health frame arouses hopeful emotions about climate change. Climatic Change 2012;113:11051112. Available from: https://link.springer.com/article/https://doi.org/10.1 007/s10584-012-0513-6, 3-4

16. Akerlof KL, Boules C, Ban Rohring E, Rohring B, Kappalman S. Governmental communication of climate change risk and efficacy: Moving audiences toward "danger control.". Environ Manag. 2020;65(5):678-88. https://doi. org/10.1007/s00267-020-01283-8.

17. Maibach EW, Nisbet M, Baldwin P, Akerlof K, Diao G. Reframing climate change as a public health issue: an exploratory study of public reactions. BMC Public Health. 2010;10(1):299. https://doi.org/10.1186/1471-2458-10-299.

18. Brenan M. Nurses again outpace other professions for nonesty, ethics. Gallup Polls [Internet]. 2018 [cited 2020 Oct 1]; Available from: https://news. gallup.com/poll/245597/nurses-again-outpace-professions-honesty-ethics.a spx

19. Adams A, Byron R, Maxwell B, Byron L, Higgins S, Eggers M, et al. Climate change and human health in Montana :A special report of the Montana Climate Assessment. Bozeman, MT: Montana State University, Institute on Ecosystems, Center for American Indian and Rural Health Equity; 2020 [cited 2021 Jan 2]. Available from: https://doi.org/https://doi.org/10.15788/c2h22 021.

20. Whitlock C, Cross W, Maxwell B, Silverman N, Alisa A. 2017 Montana Climate Assessment [Internet] 2017. Available from: https://scholarworks.montana. edu/xmlui/handle/1/13584

21. USGCRP. Fourth National Climate Assessment. Washington, DC: U.S. Global Change Research Program; 2018. [cited 2020 May 19] p. 1-470. Available from: https://nca2018.globalchange.govhttps://nca2018.globalchange.gov/ chapter/10

22. Census Viewer: Population of Montana [Internet]. 2010 [cited 2020 May 20]. Available from: http://censusviewer.com/state/MT

23. Duffin E. Population density of the United States from 1790 to 2019 in residents per square mile of land area [Internet].Statista. 2021. [cited 2021
Jan 3]. Available from: https://www.statista.com/statistics/183475/united-sta tes-population-density/.

24. U.S. Bureau of Labor Statistics. occupational employment statistics: May 2019 state occupational employment and wage estimates Montana [Internet]. [cited 2020 May 20]. Available from: https://www.bls.gov/oes/ current/oes_mt.htm

25. Montana area, size, and density [Internet]. States 101. 2014 [cited 2020 May 20]. Available from: https://www.states101.com/populations/montana

26. Leiserowitz A. Climate change risk perception and policy preferences: the role of affect, imagery, and values. Clim Chang. 2006 Jul 1;77(1-2):45-72. https://doi.org/10.1007/s10584-006-9059-9.

27. Weber EU. What shapes perceptions of climate change? New research since 2010. WIREs Climate Change. 2016;7(1):125-34. https://doi.org/10.1002/wcc.3 77.

28. Witte K. Putting the fear back into fear appeals: the extended parallel process model. Commun Monogr. 1992;59(4):329-49. https://doi.org/10.1 080/03637759209376276.

29. Rogers RW. A protection motivation theory of fear appeals and attitude change. J Psychol. 1975;91(1):93-114. https://doi.org/10.1080/00223980.1975. 9915803.

30. Hornsey MJ, Harris EA, Bain PG, Fielding KS. Meta-analyses of the determinants and outcomes of belief in climate change. Nat Clim Chang. 2016:6(6):622-6. https://doi.org/10.1038/nclimate2943.

31. Jones J. Gallup Polls Social Series: Environment. American views on global warming, 2019. Gallup Polls [Internet]. 1 [cited 2019 Nov 25]; Available from: https://news.gallup.com/poll/248030/americans-views-global-warming-2019trends.aspx?g_source=link_newsv9\&g_campaign=item_248027\&g_ medium=copy

32. Kreslake J, Sarfaty M, Roser-Renouf C, Leiserowitz A, Maibach E. The critical roles of health professionals in climate change prevention and preparedness. Am J Public Health. 2018 Apr 26.

33. Hathaway J, Maibach EW. Health implications of climate change: a review of the literature about the perception of the public and health professionals. Curr Environ Health Rep. 2018;5(1):197-204. https://doi.org/10.1007/s40572018-0190-3

34. Maibach EW, Chadwick A, McBride D, Chuk M, Ebi KL, Balbus J. Climate change and local public health in the United States: preparedness, programs and perceptions of local public health department directors. PloS One. 2008;3:e2838.

35. Roser-Renouf C, Maibach EW, Li J. Adapting to the changing climate: an assessment of local health department preparations for climate changerelated health threats, 2008-2012. PLoS One. 2016;11(3):e0151558. https:// doi.org/10.1371/journal.pone.0151558.

36. Polivka BJ, Chaudry RV, Crawford JM. Public health nurses' knowledge and attitudes regarding climate change. Environ Health Perspect. 2012;120(3): 321-5. https://doi.org/10.1289/ehp.1104025.

37. Syal S, Wilson R, Crawford JM, Lutz J. Climate change and human health - what influences the adoption of adaptation programming in the United States public health system? Mitigation Adapt Strateg Glob Change. 2011;16:911-24.

38. McAdams J, Rehr R, Kobayashi N, DeArman V. Measuring National Environmental Health Association member attitudes, awareness, and behaviors on climate change: results from three consecutive annual surveys. J Environ Health. 2019;81(8):40-3.

39. Bedsworth L. Preparing for climate change: a perspective from local public health officers in California. Environ Health Perspect. 2009;117(4):617-23. https://doi.org/10.1289/ehp.0800114.

40. Carr JL, Sheffield PE, Kinney PL. Local preparedness for climate change among local health department officials in New York state: a comparison with national survey results. J Public Health Manage Pract. 2012;18(2):E2432. https://doi.org/10.1097/PHH.0b013e31823dea74.

41. Carter JM, Koman PD, Cameron L, Ferguson A, Jacuzzo P, Duvall J. Assessing perceptions and priorities for health impacts of climate change within local Michigan health departments. J Environ Stud Sci. 2021. https://doi.org/10.1 007/s13412-021-00679-0.

42. Sarfaty M, Mitchell M, Bloodhart B, Maibach EW. A survey of African American physicians on the health effects of climate change. Int J Environ Res Public Health. 2014;11(12):12473-85. https://doi.org/10.3390/ ijerph111212473.

43. Sarfaty M, Bloodhart B, Ewart G, Thurston GD, Balmes JR, Guidotti TL, et al. American Thoracic Society member survey on climate change and health. 
Ann Am Thorac Soc. 2015;12(2):274-8. https://doi.org/10.1513/AnnalsATS.2 01410-460BC.

44. Sarfaty M, Kreslake JM, Casale TB, Maibach EW. Views of AAAAl members on climate change and health. J Allergy Clin Immunol Pract. 2016;4(2):333-335.e26.

45. Vynne S, Doppelt B. Climate change health preparedness in Oregon: An assessment of awareness, preparation and resource needs for potential public health risks associated with climate change. Eugene OR: The Climate Leadership Initiative with The Oregon Coalition of Local Health Officials, Environmental Health Committee; 2009. [cited 2021 Feb 2]. Available from: https://tools.niehs.nih.gov/cchhl/index.cfm/main/detail?reference_id=1142

46. State and territorial health agency needs for a changing climate: $\mathrm{A}$ summary and analysis of ASTHO's 2009 and 2012 climate health needs assessments [Internet]. 2012 [cited 2021 Feb 21]. Available from: https:// www.astho.org/Programs/Environmental-Health/Natural-Environment/Clima te-Change/2012-Climate-and-Health-Survey-Report/

47. Are We Ready? Report 2: Preparing for the public health challenges of climate change [Internet]. National Association of County and City Health Officials (NACCHO); 2014. Available from: https://www.naccho.org/uploads/ downloadable-resources/NA609PDF-AreWeReady2.pdf

48. EcoAmerica, Lake Resource Partners. American Climate Metrics Survey: NEHA September 2017 [Internet]. ecoAmerica; 2017 [cited 2021 Jun 29]. Available from: https:/www.neha.org/sites/default/files/eh-topics/climate-change/ecoA merica_NEHA_Climate_Metrics_Survey_Highlights_2017_Rev.pdf

49. EcoAmerica, Lake Resource Partners. American Climate Metrics Survey: NEHA September 2016 [Internet]. ecoAmerica; 2017 [cited 2021 Jun 29]. Available from: https://www.neha.org/sites/default/files/eh-topics/climatechange/ecoAmerica_Climate_Survey_NEHA_US_Results_Sum_2016_09.pdf

50. van der Linden $\mathrm{S}$. The social-psychological determinants of climate change risk perceptions: towards a comprehensive model. J Environ Psychol. 2015; 41:112-24. https://doi.org/10.1016/j.jenvp.2014.11.012.

51. Konisky DM, Hughes L, Kaylor CH. Extreme weather events and climate change concern. Clim Chang. 2016 Feb 1;134(4):533-47. https://doi.org/10.1 007/s10584-015-1555-3.

52. Dolce C. Extreme fall start marked by unusual heat, snow and cold records in the United States. 2019 [cited 2020 Jun 10]; Available from: https:/wea ther.com/news/news/2019-10-02-fall-extreme-weather-snow-coldnorthwest-east-heat-lorenzo

53. National Interagency Fire Center. [cited 2020 Jun 10]. Available from: https:// www.nifc.gov/firelnfo/firelnfo_statistics.html

54. Leiserowitz A, Maibach E, Rosenthal S, Kotcher J, Bergquist P, Ballew MT, et al. Climate Change in the American mind: April 2020. In: Yale University and George Mason University. New Haven, CT: Yale Program on Climate Change Communication; 2020. Available from: https://climatecommunica tion.yale.edu/wp-content/uploads/2020/05/climate-change-american-mind-a pril-2020b.pdf.

55. Jones J. Conservatives greatly outnumber liberals in 19 U.S. states [Internet]. Gallup Polls. 2019 [cited 2020 Jun 10]. Available from: https://news.gallup. com/poll/247016/conservatives-greatly-outnumber-liberals-states.aspx

56. Montana gender ratios 2019. States 101. 2019 [cited 2020 Dec 1]. Available from: https://www.states 101.com/gender-ratios/montana

57. Myers TA, Maibach EW, Roser-Renouf C, Akerlof K, Leiserowitz AA. The relationship between personal experience and belief in the reality of global warming. Nat Clim Change. 2013;3(4):343-7. https://doi.org/10.1038/nclima te 1754 .

58. Leiserowitz A, Maibach E, Roser-Renouf C, Rosenthal S, Cutler M, Kotcher J. Politic and global warming, March 2018. [Internet]. Yale Center on Climate Change Communication. 2018 [cited 2020 Mar 1]. Available from: https:// climatecommunication.yale.edu/publications/politics-global-warming-ma rch-2018/2/

59. Janson J. The civic and community engagement of religiously active Americans [Internet]. Pew Research Center. 2011 [cited 2020 Jun 10]. Available from: https://www.pewresearch.org/internet/2011/12/23/thecivic-and-community-engagement-of-religiously-active-americans/

\section{Publisher's Note}

Springer Nature remains neutral with regard to jurisdictional claims in published maps and institutional affiliations.

\section{Ready to submit your research? Choose BMC and benefit from}

- fast, convenient online submission

- thorough peer review by experienced researchers in your field

- rapid publication on acceptance

- support for research data, including large and complex data types

- gold Open Access which fosters wider collaboration and increased citations

- maximum visibility for your research: over $100 \mathrm{M}$ website views per year

At BMC, research is always in progress.

Learn more biomedcentral.com/submissions 